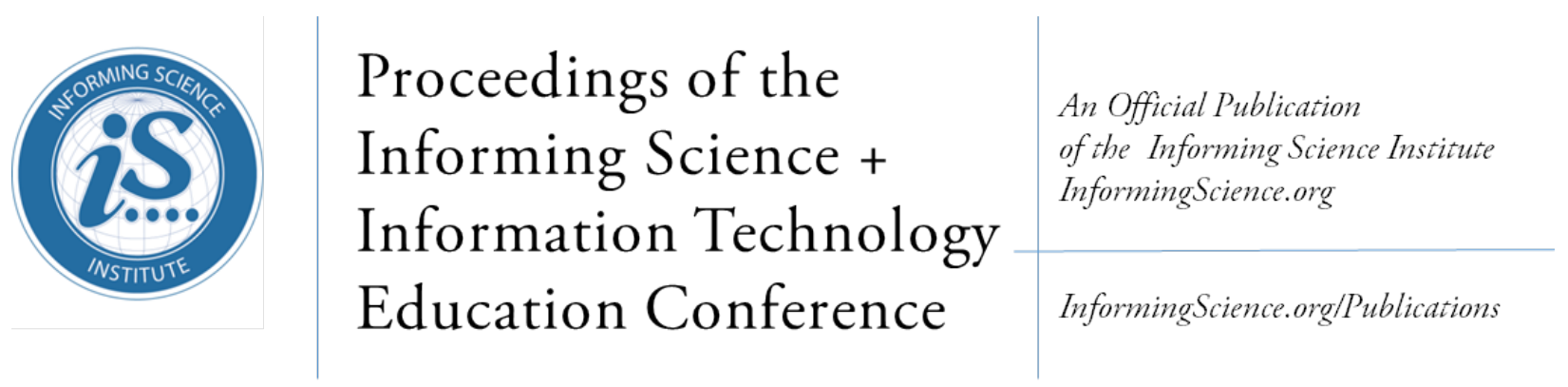

June 30 - July 4, 2019, Jerusalem, Israel

\title{
ENGAGING MARITIME STUDENTS IN LIFELONG LEARNING as TEACHER'S PRIME MISSION [ABSTRACT]
}

Olga Zavalniuk*

Volodymyr Nesterenko

Inna Zavalniuk

* Corresponding author
Kherson State Maritime Academy, Kherson, Ukraine

Kherson State Maritime Academy, Kherson, Ukraine

Kherson State Maritime Academy, Kherson, Ukraine olgazavalnjuk82@gmail.com

nesterenko mast@mail.ru

zavalnyukinna@gmail.com

\section{ABSTRACT}

Aim/Purpose

The present research is devoted to teaching and training students in marine institutions of higher education including navigators that given the dynamic development of the maritime industry should still be in the early stages of education involved by teacher to lifelong learning and be able to teach others.

Background The rapid development of the marine industry, modern ship technical equipment, the constant tightening of requirements for ship owners in the environmental protection and cyber security fields are forcing teachers of maritime educational institutions to constantly improve their approaches to training future maritime specialists competitive in the labour market. The present study shows some solutions to this problem.

Methodology The used methodical methods are observations, conversations, questionnaires, analysis of students' coursework and diploma papers, cadets rating. The basis of the research is a detailed analysis of the studying process of the academic discipline "Ship's theory and design" by cadets of the Marine Academy.

Contribution Ways to create the cadet's and the future marine specialist's ability to constantly develop and learn during his professional life as well as be able to be a mentor are presented.

Findings The study found that within the framework of the teacher's main mission in marine education and in accordance with the conducted research mastery of competencies by the future navigator takes place in several important and dif-

Accepted by Executive Review by Editor: Eli Cohen | Received: February 15, 2019 | Revised: February 22, 2019 | Accepted: February 23, 2019.

Cite as: Zavalniuk, O., Nesterenko, V., \& Zavalniuk, I. (2019). Engaging maritime students in lifelong learning as teacher's prime mission [Abstract]. Proceedings of the Informing Science and Information Technology Education Conference, Jerusalem, Israel, pp. 449-452. Santa Rosa, CA: Informing Science Institute. https://doi.org/10.28945/4245

(CC BY-NC 4.0) This article is licensed to you under a Creative Commons Attribution-NonCommercial 4.0 International License. When you copy and redistribute this paper in full or in part, you need to provide proper attribution to it to ensure that others can later locate this work (and to ensure that others do not accuse you of plagiarism). You may (and we encourage you to) adapt, remix, transform, and build upon the material for any non-commercial purposes. This license does not permit you to use this material for commercial purposes. 
Recommendations Possible application of the research results in the training of specialists from for Practitioners

ferent substantive directions. Among them there is a classical theoretical and practical training (in the laboratory and on board); investigation of accidents occurring in the world in the fleet; participation in research work with trainers, membership in international and local maritime communities and mentoring and as an extra result the formation of students' critical and creative thinking.

Recommendation for Researchers other various sectors of the economy.

The importance of introducing a competency approach (Competency Based Education) in the initial training of specialists in the maritime industry is emphasized in this paper. Therefore, it will be relevant for researchers in related areas.

Impact on Society Developing a student's ability to lifelong learning, being ready to understand and adopt technological progress is a possible way to form a conscious, healthy member of society.

Future Research The effectiveness of distance education and applying of innovative technologies in the navigators training is a priority research area.

Keywords competency based education, higher education, creative thinking, critical thinking, mentors

\section{INTRODUCTION}

The maritime industry has always been and remains one of the leading industries in the world economy. This requires the presence of highly skilled, competitive specialists (marine fleet officers) with the ability to quickly and flexibly to learn and to train their subordinates to adjust to continuous progressive changes in the ships' technical equipment, changes in maritime legislation, other modern requirements of the international maritime organization, classification societies and so on. According to research data of Gilbert Maturan, Global Training Manager at Teekay in 2016 (Maturan, 2016): " $60 \%$ of learning occurs onboard, through practical, hands-on experience $30 \%$ takes place through interaction with peers (coaching and mentoring), 10\% comes from formal, short courses taken while ashore". That is why qualitative primary basic education is extremely important in the marine specialist's training. In the educational process of the Kherson State Maritime Academy (KSMA, Ukraine) the competence approach (Casey \& Sturgis, 2018; International Convention on Standards of Training, 2011) has been a leading direction for decade in the initial training of specialists in the maritime industry in particular navigators and teaching the cadet "never stop to learn" is the main teacher's mission of the Maritime Academy in modern conditions of the marine industry development.

\section{RESEARCH QUESTIONS. MAIN PURPOSE}

The Bachelor of Navigation is a specialist who in accordance with the requirements of the International Convention on Standards of Training, Certification and Watchkeeping for Seafarers (International Convention on Standards of Training, 2011) is able to carry out a number of important functions and complex tasks that require a wide range of knowledge and skills and the ability to continuously learning and improving during their professional career. In the curriculum of the KSMA for the development of professional competencies a set of special disciplines was provided which in the amount of time makes up about $80 \%$ of the entire curriculum. The main purpose of the research is to find ways to realize the main teacher's goal namely: "to teach the student never to stop learning and to be able to teach subordinates", basing on an example of one of the special courses "Ship's theory and design" for maritime specialist training and on the own experience of its teaching by the authors. 


\section{RESEARCH METHODS}

The scientific research consisted in the systematic data collection and analysis over the learning process for ten years in the maritime education field and was based on authors' own experience of teaching professional disciplines for future navigators. During the study observations, conversations, questionnaires, analysis of students' coursework and diploma papers, cadets rating were used.

\section{MAIN RESULTS}

In the navigator's training educational program it is provided a classical training course "Ship's theory and design" which is basic and intended to provide future navigator with knowledge, skills and abilities to control the ship's stability and strength during its operation ensuring the ship's navigation in different conditions. According to (International Convention on Standards of Training, 2011, Model Course 7.03, 2014), it should be attributed to the sphere of navigator's competence: "Plan and ensure safe loading, stowage, securing, care during voyage and unloading of cargoes" and "Control trim, stability and stress". 10 years ago, according to the survey data by the educational research laboratory "Ship's theory, design and maritime safety" of KSMA 95\% of cadets on the vessel could not clearly link own theoretical knowledge, received on the shore from the specified discipline with practical tasks for the creation of a ship's cargo plan which was required to carry out during their professional activities. The construction of the discipline "Ship's theory, design and maritime safety" in such a way that the course was more applied in character than the theoretical consistent with the world trends namely: "Continuing Professional Development (CPD)" of a marine specialist (Gosling, 2015) and had a single practical and applied core structure for example, the ship's cargo plan is the main achievement of the authors' research. According to the data by the laboratory at the moment more than $50 \%$ of cadets who have studied advanced programs while in the process of passing the work practice, confidently carry out practical tasks within the framework of the above competencies.

\section{PRACTICAL IMPLICATIONS - IMPORTANCE OF THE RESEARCH}

The cadets in their professional activities were held five distinct stages in accordance with the popular model of skill acquisition (Gosling, 2015): novice, competence, proficiency, expertise, and mastery, which proves the acquired ability of the Academy's graduate "never stop learning". The basis of maritime students' training is the slogan: 'it's better to investigate someone else's accident than to investigate their own". They are actively monitoring the reports in the press about cases of serious marine accidents collecting relevant materials available in the open press, analyzing cases making their own conclusions which contributes to the development of cadets' critical thinking. Students are active researchers in relevant scientific issues related to the maritime safety. They actively participate in scientific measurements and experiments on ships, publish articles on the results of own research, developing creative thinking. Mentoring is a great way not only to help their colleagues or future subordinates but also to develop their knowledge and skills on the principle: "teaching, I understand more myself". The experience of studying at the KSMA is indicative as evidenced by the fact that more than $50 \%$ of marine officers in the world are those who have completed their education in Ukrainian maritime institutions of higher education.

\section{CONCLUSION}

The positive experience and results of the described researches enable the authors to integrate them into the full educational program of training navigators as well as into the curricula of other special disciplines. The authors also intend to conduct research not only on assessing the quality of training cadets during distance learning, but also on the effectiveness of the use of the training complex "Virtual-Real Ship of the Marine Industry" in the Kherson State Maritime Academy's educational process. 


\section{REFERENCES}

Casey, K., \& Sturgis, C. (2018). Levers and logic models: A framework to guide research and design of high-quality competency-based education systems (Competency Works Report). Vienna: iNACOL. (ERIC Document Reproduction Service No. ED590519).

Gosling, S. (2015). Continuing Professional Development (CPD): The formal side of lifelong learning. The Navigator, 9, 4-5.

International Convention on Standards of Training, Certification and Watchkeeping for Seafarers (2011). London : IMO. Ashford Press.

Maturan, G. (2016). Building on competence. The Navigator, 11, 6-7.

Model Course 7.03 Officer in charge of a navigational watch (2014). London : IMO.

\section{BIOGRAPHIES}

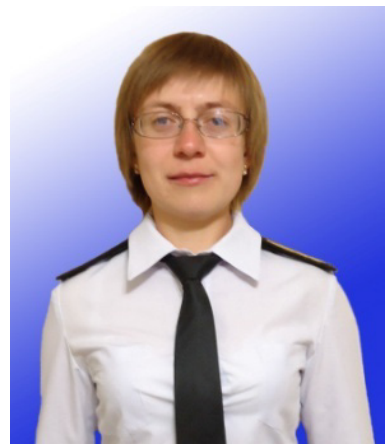

Olga Zavalniuk was born on the $3^{\text {rd }}$ of August, 1982. Associate professor of Marine electrical and automation equipment operation department of Ship Power Engineering faculty in Kherson State Maritime Academy (Ukraine). Master's degree in automated control of technological processes (2009).

Candidate of technical sciences' degree (2014). Member of The Nautical Institute (London, UK) (2016).

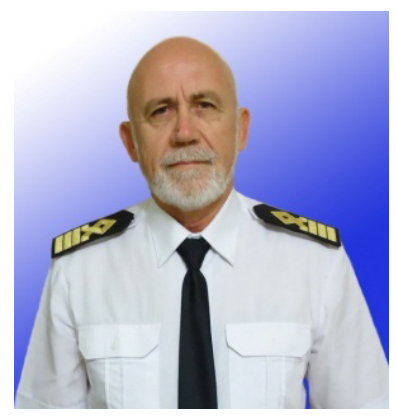

Volodymyr Nesterenko was born on the 16th of May, 1945. Deep sea captain. Senior Lecturer of Ship Handling department of Navigation faculty in Kherson State Maritime Academy (Ukraine). Degree in the field of study «Marine transport operation», qualification of Marine transport operating manager (1977). Member of The Nautical Institute (London, UK) (2017).

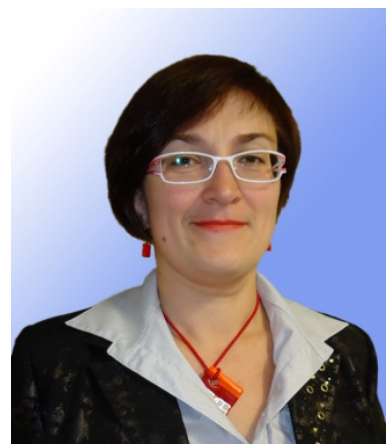

Inna Zavalniuk was born on the 20 $0^{\text {th }}$ of July, 1980. Associate Professor of Ship Handling department of Navigation faculty in Kherson State Maritime Academy (Ukraine). Master's degree in automated control of technological processes (2003). Candidate of technical sciences' degree (2011). 